Journal of Environmental Sciences
JOESE 5
ISSN 2090-9233
Journal homepage http://Joese.mans.edu.eg

Original Article

\title{
Biological Assessment of Water Toxicity and Fertility of Wastewater Omer Bek Drain Discharging into Receiving Water of the River Nile in Egypt
}

\author{
Ghada S. Abou-EI Wafa; Sara S. Ibrahim and Mohammad I. Abdel-Hamid \\ Botany Department, Faculty of Science, Mansoura University, Egypt
}

\begin{tabular}{|c|c|}
\hline Article Info & Abstract \\
\hline $\begin{array}{l}\text { Keywords: } \\
\text { Drainage water } \\
\text { Algal growth potential (AGP) } \\
\text { Eutrophication and heavy metal }\end{array}$ & $\begin{array}{l}\text { Water toxicity and fertility of a drain wastewater discharging wastewater directly to the } \\
\text { Damietta branch of the River Nile were seasonally investigated from winter to autumn, } \\
2016 \text {. Nutrient enrichment bioassays to define the algal growth limiting nutrients, their } \\
\text { bioavailability and heavy metal toxicity of the sampled water, were carried out with the ISO } \\
\text { standard test alga Pseudokirchneriella subcapitata. The algal growth potential (AGP) test } \\
\text { exhibited a wide range of growth potential ranging from } 0.4 \mathrm{mg}^{-1} \mathrm{l}^{-1} \text { to } 19.42 \mathrm{mg} . \mathrm{l}^{-1} \text { algal dry } \\
\text { weight. At drain, mixing and recovery stations the algal growth was mainly limited by } \\
\text { heavy metals toxicity with inhibition percent at day } 14 \text { of growth }\left(\% \mathrm{I}_{14)} \text { ranged between }\right. \\
27.9 \text { and } 58.6 \text { while at the upstream reference station, } \% \mathrm{I}_{14} \text { ranged between } 20 \text { and } 37 \text {. The } \\
\text { algal growth was also limited by } \mathrm{N} \text { and P depending on site and season. In all seasons, but } \\
\text { only at drain station, the expected Chl. a was significantly higher than the observed Chl. a, } \\
\text { however, the reverse was held true for other sampling stations during this study. The } \\
\text { relationships between the chemically analyzed nutrients }(\mathrm{P} \text { and } \mathrm{N}) \text { and their bioavailable } \\
\text { concentrations were greatly affected by heavy metal toxicity. The results indicated that the } \\
\text { observed chlorophyll a showed significant correlations with TDP }(\mathrm{r}=0.82) \text {, while the } \\
\text { expected chlorophyll a correlated significantly with } \mathrm{NH} \mathrm{H}_{4}-\mathrm{N}(\mathrm{r}=0.73) \text {. The algal growth } \\
\text { potential test proved a sensitive and reliable mean to assess water fertility and toxicity of } \\
\text { polluting drains and the receiving waters. }\end{array}$ \\
\hline
\end{tabular}

\section{Introduction}

For decades, the algal growth potential test(AGPT) has been evolved and accepted as a standard method for the determination of bio availability of nutrients $(\mathrm{N}$ and $\mathrm{P})$ for microalgae and assessing the fertility and metal toxicity of different waterbodies all over the world (Skulbreg,1967 \& 1975; EPA, 2002; Miller et al., 1978 ; Forsberg et al. 1978; Källqvist,1975 \& 1984; Golterman, 1983; Schultz, 1985; Raschke,1987, Abdel-Hamid et al., 1992,1993, Lópeza and Dávalos-Lind 1998; Horvatic'et al. 2011\&2013; Dávalos-Lind et al.,2013 ).The AGPT defined as the highest dry weight content reached under specific conditions which reflect the nutrient content of water sample and follows the premise that, the nutrient that occurs in smallest amount is the limiting factor to the growth of the test alga Pseudokirchneriella

\footnotetext{
* Correspondence address:

Tel.:
}

E-mail address: subcapitata (Miller et al., 1978; EPA, 1978; Kviderova, 2010). Since chemical analyses alone cannot reveal the overall effects of dissolved inorganic compounds on living photosynthetic biomass. The significance of measuring algal growth potential in water samples reveals correctly the difference between the nutrients of a sample determined by chemical analysis and the nutrients that are actually bioavailable for algal growth and the addition of given nutrients to the water sample indicate which nutrient is limiting for algal growth (Miller et al., 1974; Lukavsky, 1992; McCormick\& Stevenson 1998; EPA, 2002).

Algal growth potential (AGP) tests and limiting-nutrient assays are the most direct and effective methods for the assessment of a receiving water to determine its trophic status and sensitivity to changes in $\mathrm{N}$ and $\mathrm{P}$ loading, in addition to heavy metal toxicity. (Miller et al., 1974; Raschke and Schultz, 1987; Abdel-Hamid et al., 1992; Lukavsky, 1992; Lopez and Davalos-Lind, 1998; Shin and Cho, 2000;Kuanget al., 2004; Millican et al., 2008) 
The selective addition of nitrogen and phosphorus singly or in combination, and the addition of EDTA to the sampled water can indicate which nutrient(s) is possible limiting for algal growth, and also determine the magnitude of heavy metal inhibition to the growth of the standard test alga (Mille ret al., 1974; Greene et al., 1975; Payne, 1976; Gerhold, 1976; Greene et al., 1976; Donald et al., 2013).In Egypt the AGPtest has been developed and employed in water quality studies since 1976 (Fayed and Shehata, 1980) and was applied mainly for assessing the fertility and toxicity of the River Nile (Zahranet al., 1988; Abdel-Hamid, 1992). The present paper aims to correlate the algal growth potential (AGP) with P and $\mathrm{N}$ concentrations to evaluate limiting nutrient(s) of revering ecosystems receiving wastewater, and to assess the heavy metal toxicity.

\section{Material and Methods}

\subsection{Study area}

The main River Nile downstream of Delta (El-Qanater) Barrages divides into two branches, the eastern(Damietta) and the western (Rosetta) branch. Damietta branch begins at the Delta Barrage and ends220km downstream at Faraskour dam near Damietta. It receives excessive wastewater discharges from Omar Bek drain (Figure1).This drain, located in ElGharbia governorate, starts from Zefta City and ends at Samanoud City. The wastewater is mainly composed of untreated sewage, industrial wastewater; agricultural wastewater discharged from urban areas located lengthwise the drain. The geographical location of study area is shown in (Figure 1).

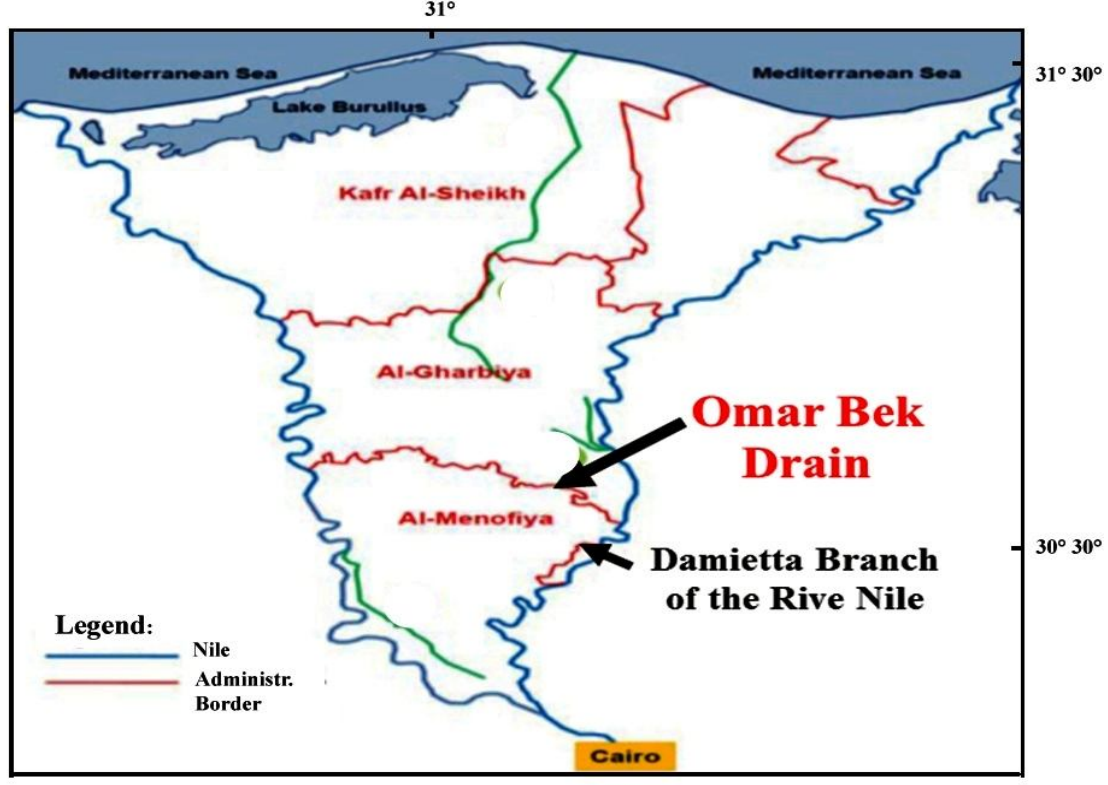

Fig.1. The geographical location of study area.

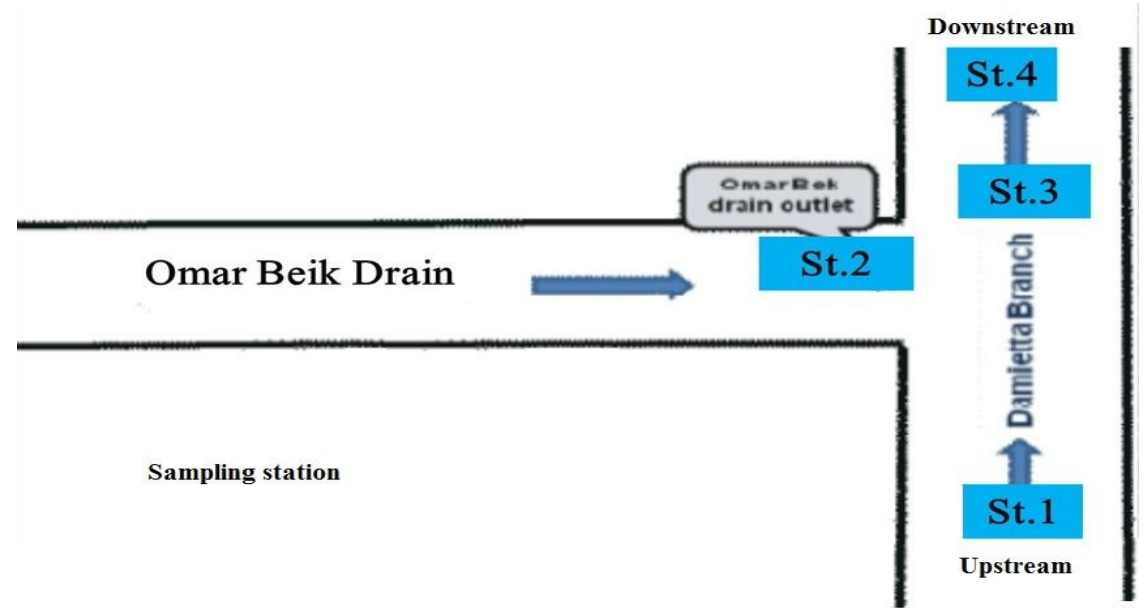

Fig.2. Schematic diagram illustrating four sampling stations 
Journal of Environmental Sciences, 2018; Vol. 47, No. 3-4 : 129-144

Table 1. Wastewater and water sampling stations

\begin{tabular}{ll}
\hline \multicolumn{1}{c}{ Sampling stations } & \multicolumn{1}{c}{ Description } \\
\hline Station1 (Reference station) & It is a riverinestation, located $300 \mathrm{~m}$ on upstream of the outlet of the drain. \\
\hline Station2 & Located 20 meter before the outlet of Omar-Bek drain. \\
\hline Station3 & $\begin{array}{l}\text { Located } 2 \text { meter downstream the outlet of Omer Bek where wastewater is } \\
\text { mixed with Nile fresh water. }\end{array}$ \\
\hline Station4 & Located at $600 \mathrm{~m}$ downstream of the outlet of the drain. \\
\hline
\end{tabular}

\subsection{Sampling}

Water samples were seasonally collected during the period from mid-winter-mid-autumn. Sample collection, handling, and processing were conducted according to EPA (1985).

\subsection{Sample preparation}

Upon arrival to the laboratory, water samples were mixed. Six liters were filtered through GF/C What man glass filters. The first one liter filtrate was discarded and five liters were stored at $4{ }^{\circ} \mathrm{C}$ in dark until used for different analyses.

\subsection{Preparation of glassware}

Glass wares were washed with non-phosphate detergent, flushed thoroughly with tap water, rinsed with $10 \%(\mathrm{v} / \mathrm{v}) \mathrm{HCl}$ solution, neutralized by swirling with a saturated sodium carbonate solution, rinsed five times with tap water followed by five rinses with deionized distilled water, dried at $50{ }^{\circ} \mathrm{C}$, plugged with cotton stoppers and stored in a closed cabinets until needed.

\subsection{Chemical analysis}

Unless otherwise stated, chemical analysis followed standard respective methods as described in APHA (1989 and 2005). The Analysis included total dissolved phosphorus (TDP), dissolved reactive phosphorus (DRP), Nitrate - N, ammonium- $\mathrm{N}$, and Nitrite - $\mathrm{N}$ was determined using the method described by (Barnes and Folkard,1951) and (Dewis and Freitas, 1970). Analysis of the heavy metals $\mathrm{Cd}, \mathrm{Cu}, \mathrm{Fe}, \mathrm{Pb}$ and $\mathrm{Zn}$ was achieved by the direct aspiration into an airacetylene flame using atomic absorption spectrophotometer type BUCK Scientific Atomic Absorption SPECTROPHOTOMETER model ACCUSYS 211 (APHA, 1989)

\subsection{Algal growth potential test (AGPT)}

The test followed (Miller et al., 1978) with green micro algae Pseudokirchneriella subcapitata Strain NIVA-CHL 1, as the standard test alga(ASTM,2004). This strain was obtained from the culture collection of the Norwegian Institute for Water Research (NIVA), Oslo, Norway.

In order to determine nutrient limitation and heavy metal toxicity, calculated amount of phosphorus, Nitrogen and $\mathrm{Na}_{2}$ EDTA were added to the GF/C filtered water samples in various concentrations according to a scheme shown in (Table 2). The test alga was grown for five days in standard Algal Assay Medium (AAM), (Mille ret al., 1978). Algal inoculum was prepared by centrifuging $100 \mathrm{ml}$ of algal suspension at $1000 \mathrm{rpm}$ for 5 minutes. The supernatant was, decanted and the residue was resuspended in sterilized distilled water. This step was repeated twice. The inoculum was left to stand for 2 hours. Three replicate culture flasks were used for each treatment listed in (Table2). The flasks were inoculated with the test alga to obtain 1000 cells $\mathrm{ml}^{-1}$ as final algal density. To avoid carbon dioxide limitation, the sample to flask volume ratio was kept in the range of 1:5. Flasks were incubated at $24 \pm 2^{\circ} \mathrm{C}$ for days and continuous illumination with cool white fluorescent tubes at $4304 \pm 10 \%$ lux (USEPA, 1978). The light intensity was measured adjacent to the culture flasks at the liquid level. To ensure free gas exchange, the culture flasks were plugged with cotton stoppers and shaken by hand once every day during the incubation period.

Table 2.Basic experimental design to determine nutrient limitation or algal growth potential test(AGPT)

\begin{tabular}{l}
\hline \multicolumn{1}{c}{ Treatments } \\
\hline Control(GF/C filtered wastewater $)$ \\
Control $+0.05 \mathrm{mg} \mathrm{P} \mathrm{l}^{-1}$ as K \\
$\mathrm{HPO}_{4}$ \\
Control $+1.00 \mathrm{~m} \mathrm{~N}^{-1}$ as NaNO \\
Control $+0.05 \mathrm{~m} \mathrm{P} \mathrm{l}^{-1}+1.00 \mathrm{mg} \mathrm{N} \mathrm{l}^{-1}$ \\
Control $+1.00 \mathrm{mg} \mathrm{Na}_{2} \mathrm{EDTA} \mathrm{l}^{-1}$ as Disodium Ethylene diaminetetraacetic acid \\
Control $+0.05 \mathrm{mg} \mathrm{P} \mathrm{l}^{-1}+1.00 \mathrm{mg} \mathrm{Na}_{2}$ EDTA l$^{-1}$ \\
Control $+1.00 \mathrm{mg} \mathrm{N} \mathrm{l}^{-1}+1.00 \mathrm{mg} \mathrm{Na}_{2}$ EDTA l$^{-1}$ \\
Control $+0.05 \mathrm{mg} \mathrm{Pl}^{-1}+1.00 \mathrm{mg} \mathrm{N} \mathrm{l}^{-1}+1.00 \mathrm{mg} \mathrm{Na}_{2}$ EDTA l$^{-1}$ \\
\hline
\end{tabular}




\subsubsection{Growth parameter}

The incubation period of days was found to be enough for the test alga to attain its maximum standing crop (MSC)(Miller et al, 1978). At the end of the incubation period, the algal cells were counted using heamocytometer with inverted microscope. The mean cell volume was calculated with a proper geometric equation .The dry weight of algal biomass was calculated according to the following formula (Kallqvist, 1990).

\section{mg dry weight $P$.subcapitatal ${ }^{-1}=$ cell counts $\left(\right.$ cells $\left.\mathrm{ml}^{-1}\right)$ $\times \mathrm{MCV}($ cubic micrometers $) \times\left(3.6 \times 10^{-7}\right)$}

\subsubsection{Determination of available $P$ and $N$ for algal growth}

The bioavailable phosphorus (BAP $\mathrm{mg}^{-1}$ ) for the growth of Pseudokirchneriellasubcapitata, was derived by dividing the growth yield (MSC) obtained with $1.00 \mathrm{mg} \mathrm{N}^{-1}$ by the phosphorus yield coefficient (430), whereas, bioavailable nitrogen (BAN mg $\mathrm{l}^{-1}$ ) was determined by dividing the growth yield obtained with $0.05 \mathrm{mg} \mathrm{P} \mathrm{l}^{-1}$ by the nitrogen yield coefficient equal to(38)(Miller et al., 1978)

\subsubsection{Determination of the expected chlorophyll a biomass}

The expected chlorophyll a represents the maximum mean corrected chlorophyll a biomass that the wastewater or water sample can support under optimum growth conditions. It was calculated according to the equation $\left(\log _{10} \mathrm{Chl} . \mathrm{a}=1.15\right.$ $\log _{10}($ dry weight $\left.)+0.95\right)$, proposed by (Raschke \& Schultz, 1987).

\subsubsection{Determination of the observed or actual chlorophyll a}

The observed chlorophyll a represents the algal standing crop biomass at the time of sampling. One liter was filtered onto GF/C filters. The filters were ground using tissue grinder in presence of cooled $90 \%$ acetone and kept in dark for 12 hours at $4{ }^{\circ} \mathrm{C}$ for extraction. Spectrophotometric determination of chlorophyll a was carried out according to the trichromatic method described in (APHA, 1985).

\subsubsection{Assessment of heavy metal toxicity}

The heavy metal toxicity was reported as the percent (\%) of inhibition at 14 day $\left(\% \mathrm{I}_{14}\right)$ based on the difference in $\mathrm{mg}$ algal dry weight $1^{-1}$ obtained in EDTA treated and control cultures.

$$
\% \mathrm{I}_{14}=\frac{\operatorname{MSC}(\mathrm{C}+\mathrm{EDTA})-\mathrm{MSC}(\mathrm{C})}{\operatorname{MSC}(\mathrm{C}+\mathrm{EDTA})} \times 100
$$

\subsection{Statistical analysis}

A proposed percent coefficient of variance guideline (Table3), which is basically adopted from (Miller et al., 1978) and modified by (Abdel-Hamid et al., 1992), was used to a certain whether or not the differences obtained in algal maximum standing crop (MSC), between different treatments and the control cultures, are statistically significant. Regression and multiple correlation analysis were carried out using STATGRAPHICS (STSC, ver 4.2) programmer. The correlation coefficient differed significantly from zero at $p<$ 0.05 .

Table3. A proposed \% coefficient of variance guideline to ascertain whether or not the differences obtained in algal maximum standing crop (MSC) between different treatments and control cultures are statistically significant (adopted from MILLER et al ., 1979, and modified by Abdel-Hamid et al., 1992).

\begin{tabular}{|c|c|c|c|}
\hline MSC of control cultures & $\% \mathrm{C} . \mathrm{V}$ & Statistical difference & Designation in text \\
\hline \multirow{3}{*}{$<1.0 \mathrm{mg}$ dry wt/l } & $\pm 50- \pm 75$ & Significant & $*$ \\
\hline & $\pm 75- \pm 100$ & Highly significant & $* *$ \\
\hline & $> \pm 100$ & Very high significant & $* * *$ \\
\hline \multirow{3}{*}{$>1.0 \mathrm{mg}<3.0 \mathrm{mg}$ dry wt $/ 1$} & $\pm 30- \pm 45$ & Significant & $*$ \\
\hline & $\pm 45- \pm 60$ & Highly significant & $* *$ \\
\hline & $> \pm 60$ & Very high significant & $* * *$ \\
\hline \multirow{3}{*}{$>3.00 \mathrm{mg}<10.0 \mathrm{mg}$ dry wt $/ 1$} & $\pm 20- \pm 30$ & Significant & $*$ \\
\hline & $\pm 30- \pm 40$ & Highly significant & $* *$ \\
\hline & $> \pm 40$ & Very high significant & $* * *$ \\
\hline \multirow{3}{*}{$>10 \mathrm{mg}$ dry wt/l } & $\pm 10- \pm 15$ & Significant & $*$ \\
\hline & $\pm 15- \pm 20$ & Highly significant & $* *$ \\
\hline & $> \pm 20$ & Very high significant & $* * *$ \\
\hline
\end{tabular}

$\% \mathrm{C} . \mathrm{V}$ is the percent coefficient of variance $=$ sample standard deviation $/$ mean $\times 100$ 


\section{Results}

\subsection{Algal growth potential (AGP)}

The results of AGP (Figures. 3, 4, $5 \& 6$ ) are reported as the mean maximum standing crop (mg dry wt $\mathrm{l}^{-1}$ ) of the test alga grown for days at different treatments (Table 2), under optimum growth conditions. The algal growth potential showed marked local and seasonal variations. It exhibited a wide range of growth potential ranging between $0.4 \mathrm{mg} . \mathrm{l}^{-1}$ and $19.42 \mathrm{mg}^{-1} \mathrm{l}^{-1}$ of algal dry weight. From the visual inspection of AGP figures (Figures 3-6) the growth of the test alga showed a number of distinct responses of the test alga towards different water qualities and treatments including the following:

1) The GF/C filtered wastewater collected from the drain station 2 supported the highest maximum standing crop (MSC) of tested alga (7.1- 9.9mg dry wt $\mathrm{l}^{-1}$ ) followed by samples collected from the mixing zone (station 3 ) where wastewater mixes with freshwater (0.6-3.7 $\mathrm{mg}$ dry wt $\left.\mathrm{l}^{-1}\right)$. Followed by the water sample collected from station 4(proposed recovery station) (0.93 $-2.5 \mathrm{mg}$ dry wt $\left.\mathrm{l}^{-1}\right)$. The least MSC was generally supported by water samples collected from the upstream reference station $(0.4$ to 0.9 mgdrywtl $^{-1}$ )

2) Compared to the control cultures, the EDTA treatments resulted in an significant increase in MSC, suggesting the role of heavy metal toxicity or bioavailability as growth limiting factors (Figures 3a,4a,5a and 6a)

3) For most cases, the addition of $P$ caused a significant increase in MSC indicating P limitation conditions of the wastewater and water samples in all station expect drain station2.

4)The increase in algal biomass, due to the combined addition of $\mathrm{P}$ and EDTA, was significantly higher than in case of single $\mathrm{P}$ addition. This finding indicates that the growth, of the test alga, was primarily limited by heavy metal toxicity and secondarily by $\mathrm{P}$ (Figures $3 \mathrm{~b}, 4 \mathrm{~b}, 5 \mathrm{~b}$ and $6 b)$.

5) The addition of N, singly or in combination with EDTA, to wastewater samples collected from station 2 , resulted in a remarkable and significant increase in algal biomass
( Figures $3 c, 4 c, 5 c$ and $6 c$ ).In this particular case (station 2 ), the AGP was primarily limited by heavy metal toxicity and secondarily by nitrogen.

6) Compared to control cultures the combined P and $\mathrm{N}$ additions caused significant increase in algal biomass (Figures 3d,4d,5d and 6d). Generally, the combined additions of P\&N and EDTA supported the maximum standing crop of test alga, in almost cases.

\subsection{Relationship between chemically analyzed nutrients $(\mathrm{P} \& \mathrm{~N})$ and their bioavailable concentrations.}

Table 4 lists the local and seasonal variations of TSIN and TDP along with their bio-available concentrations during the period of study. It is clear that the sampling station 2 (waste water discharged from Omar Bek drain into the River Nile) contained the highest concentrations of ammonia-N, Nitrate- $\mathrm{N}$, Nitrite-N and total dissolved phosphorus (TDP) discharged into the downstream receiving water of the River Nile. Quantitative information about the relationship between the nutrients and their bioavailable concentrations, in presence and absence of heavy metal toxicity, are presented in (Table5) indicate that the highest concentration of BAN and BAP in $\mathrm{N}$ - limitation condition. Remarkable local and seasonal variations did exist in ratios between the chemically analyzed nutrients and their bioavailable concentrations calculated from the results of the algal growth potential test. For instance during summer the \% BAP/TDP were (1.4 and 8.57) and $\%$ BAN/TSIN were 3.2 and 17.65 at station 1 (Ref.) and station 2 , respectively. These ratios at both stations exhibited clear seasonal variations. One clear observation was that, in almost all cases the addition of $\mathrm{Na}_{2}$ EDTA to test culture resulted in obvious increase in bioavailability of both $\mathrm{N}$ and $\mathrm{P}$, but with remarkable local and seasonal variations were recorded. For instance, only $10 \%$ of the total dissolved phosphorus was available for the test alga grown in filtered water sample collected from station 4 during spring, however, upon EDTA addition the \% BAP/ TDP, of the same water sample, increased to 20 (Table 5). Also, the \%BAN/TSIN of the water sample, collected from station 2 (drain) during autumn, was 12.57 and 23.27 before and after EDT Aaddition respectively. 
Journal of Environmental Sciences, 2018; Vol. 47, No. 3-4 : 129-144
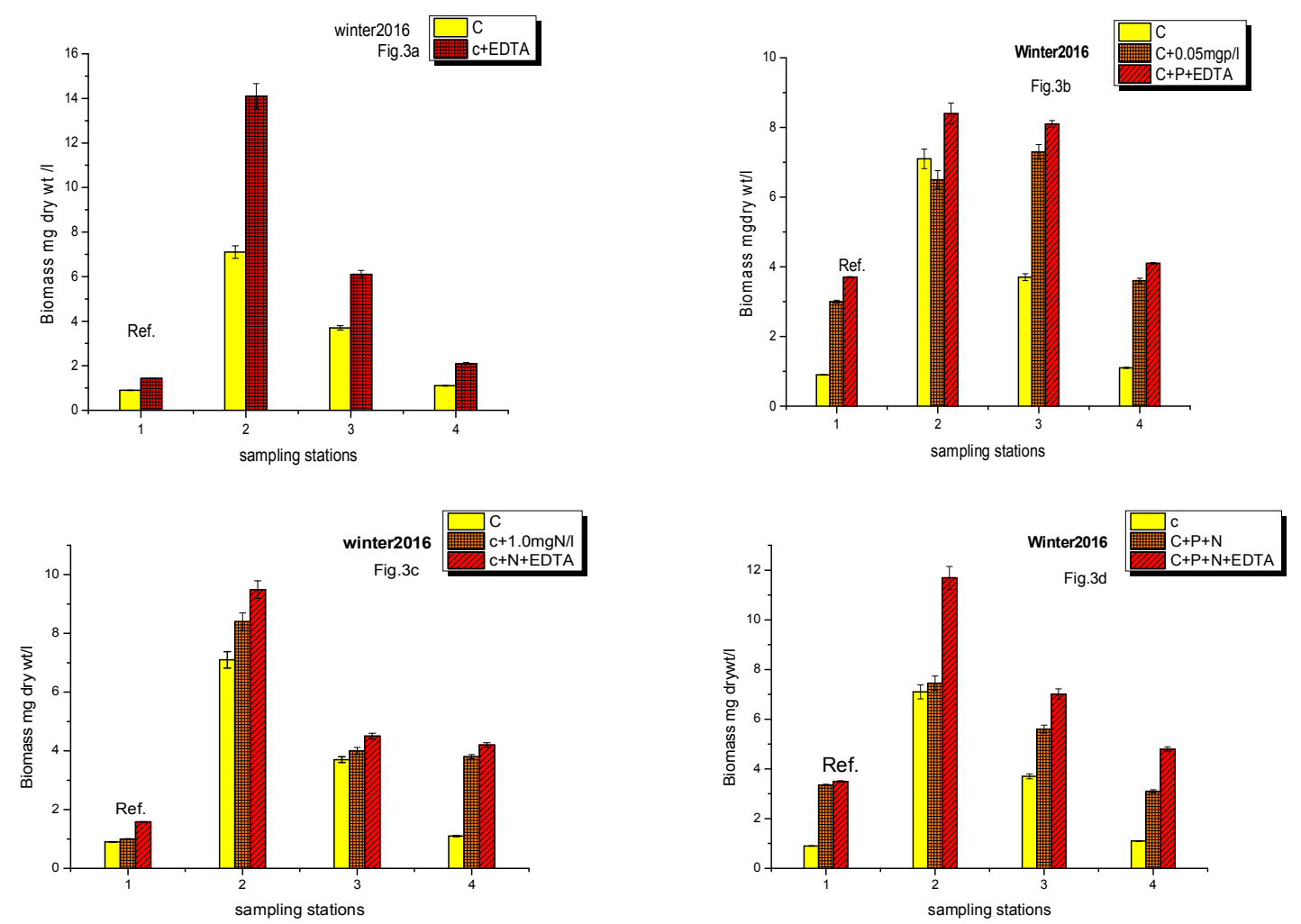

Fig.3. Algal growth potential of the study area during mid -winter (2016).
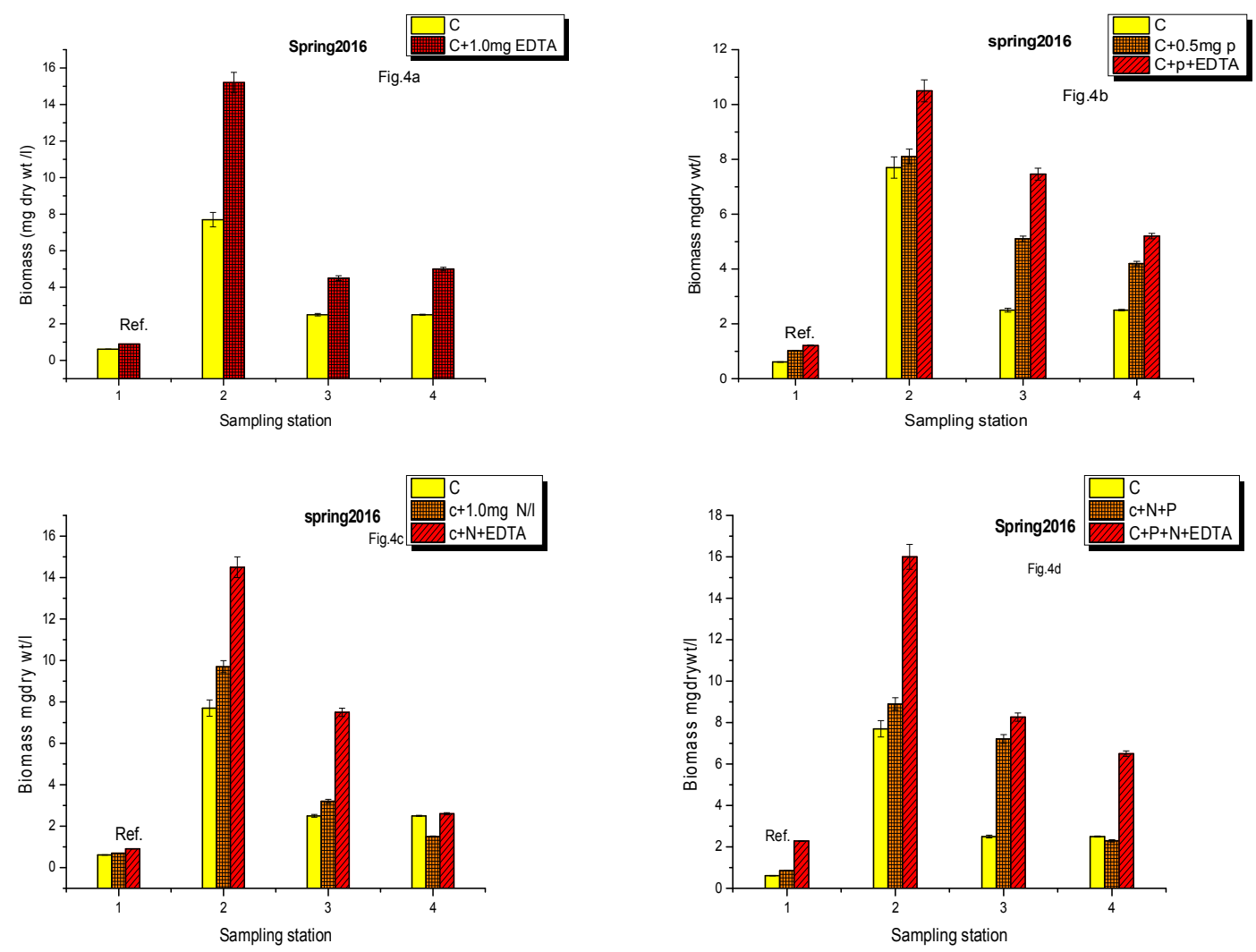

Fig. 4. Algal growth potential of the study area during mid -spring (2016) 

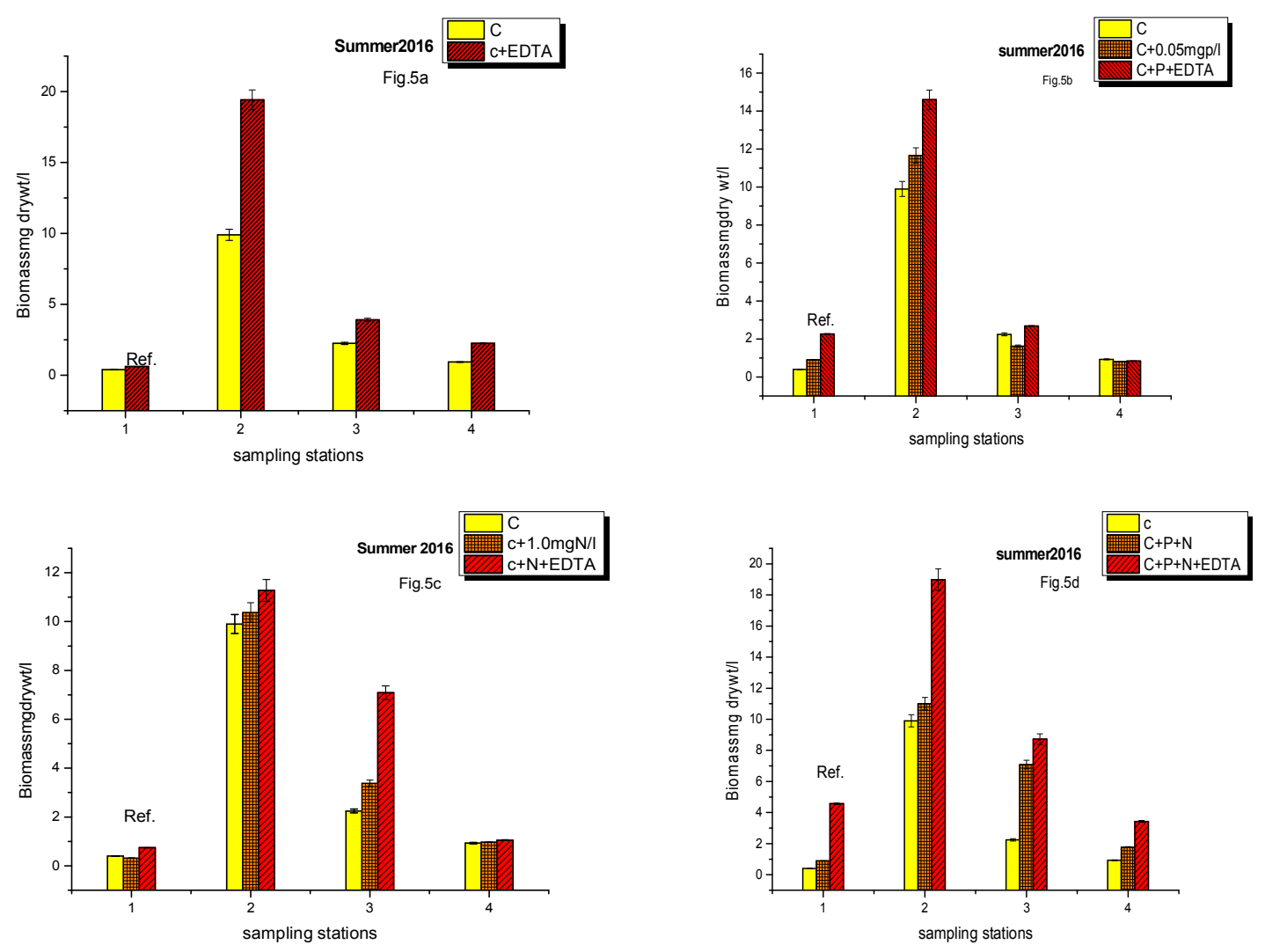

Fig. 5.Algal growth potential of the study area during mid -summer (2016).
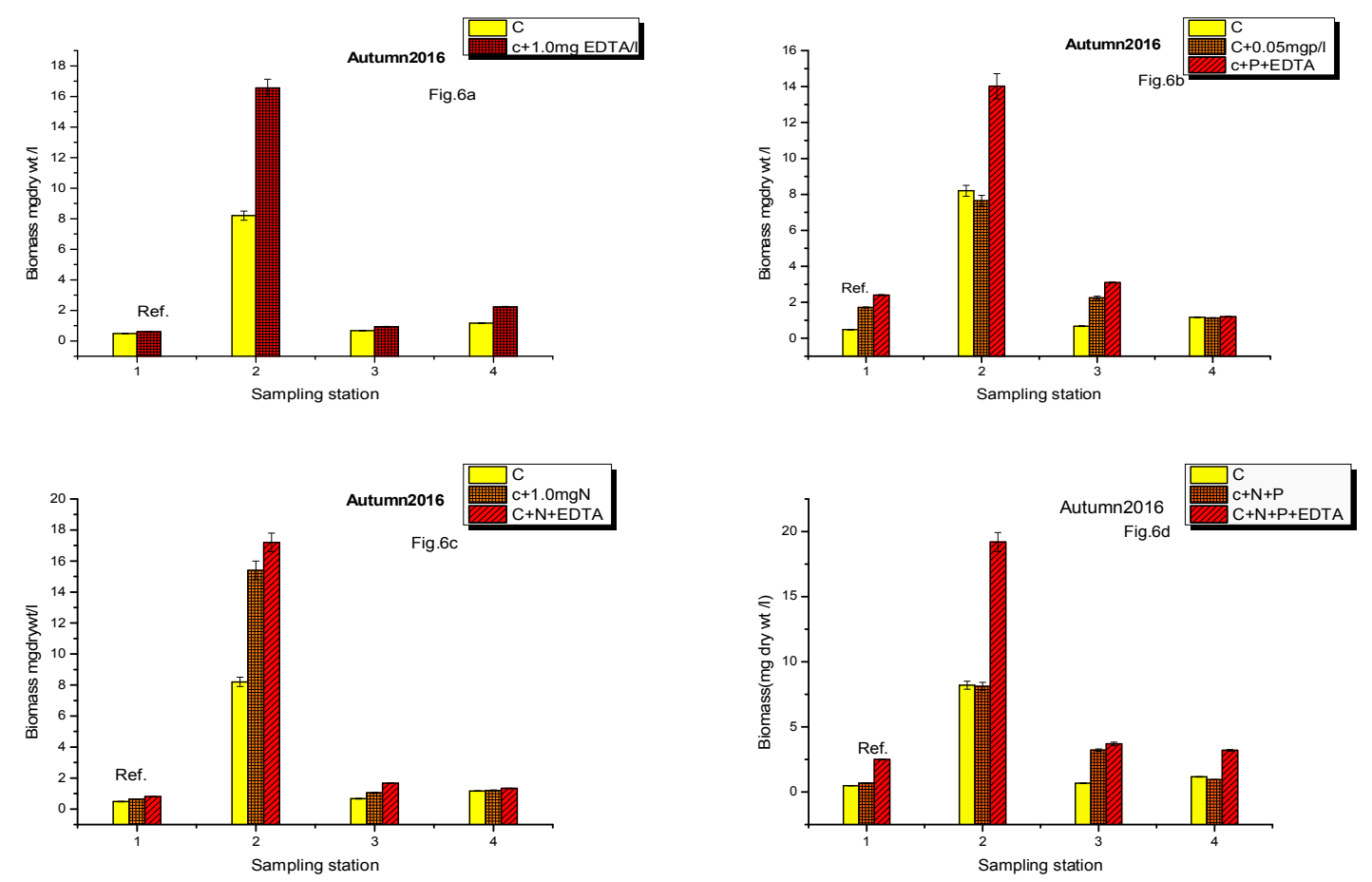

Fig. 6. Algal growth potential of the study area during mid-autumn 2016. 
Journal of Environmental Sciences, 2018; Vol. 47, No. 3-4 :129-144

Table 4. Local and seasonal variations in concentration $\left(\mathrm{mgl}^{-1}\right.$, Mean $\pm \mathrm{SD}$ ) of nitrite-N, nitrate-N, ammonium-N (collectively known as total soluble inorganic nitrogen) and total dissolved phosphorus (TDP) and their bioavailable concentration.

\begin{tabular}{|c|c|c|c|c|}
\hline \multirow{3}{*}{ Parameter } & \multicolumn{4}{|c|}{ Stations } \\
\hline & 1 (ref) & 2 & 3 & 4 \\
\hline & \multicolumn{4}{|c|}{ Winter } \\
\hline NH4-N & $0.2 \pm 0.01$ & $1.17 \pm 0.05$ & $1.05 \pm 0.04$ & $0.3 \pm 0.009$ \\
\hline $\mathrm{NO} 2-\mathrm{N}$ & $0.035 \pm 0.01$ & $0.06 \pm 0.003$ & $0.05 \pm 0.002$ & $0.04 \pm 0.001$ \\
\hline NO3-N & $0.22 \pm 0.004$ & $0.5 \pm 0.025$ & $0.26 \pm 0.01$ & $0.25 \pm 0.007$ \\
\hline TSIN & $0.45 \pm 0.009$ & $1.73 \pm 0.08$ & $1.36 \pm 0.05$ & $0.59 \pm 0.017$ \\
\hline TDP & $0.047 \pm 0.001$ & $0.57 \pm 0.03$ & $0.32 \pm 0.01$ & $0.08 \pm 0.002$ \\
\hline BAP & 0.00230 .001 & 0.0190 .001 & 0.0090 .01 & $0.008 \pm 0.0002$ \\
\hline \multirow[t]{2}{*}{ BAN } & $0.07 \pm 0.00$ & $0.17 \pm 0.0008$ & $0.19 \pm 0.007$ & $0.09 \pm 0.003$ \\
\hline & \multicolumn{4}{|c|}{ Spring } \\
\hline NH4-N & $0.21 \pm 0.004$ & $0.74 \pm 0.04$ & $0.65 \pm 0.03$ & $0.4 \pm 0.01$ \\
\hline $\mathrm{NO} 2-\mathrm{N}$ & $0.03 \pm 0.006$ & $0.04 \pm 0.002$ & $0.038 \pm 0.002$ & $0.036 \pm 0.001$ \\
\hline NO3-N & $0.05 \pm 0.001$ & $0.24 \pm 0.01$ & $0.06 \pm 0.002$ & $0.058 \pm 0.002$ \\
\hline TSIN & $0.3 \pm 0.006$ & $1.02 \pm 0.05$ & $0.72 \pm 0.03$ & $0.49 \pm 0.01$ \\
\hline TDP & $0.024 \pm 0.001$ & $0.59 \pm 0.03$ & $0.23 \pm 0.009$ & $0.03 \pm 0.002$ \\
\hline BAP & $0.0016 \pm 0.0001$ & $0.022 \pm 0.001$ & $0.007 \pm 0.0003$ & $0.003 \pm 0.0002$ \\
\hline \multirow[t]{2}{*}{ BAN } & $0.026 \pm 0.001$ & $0.21 \pm 0.01$ & $0.13 \pm 0.005$ & $0.11 \pm 0.003$ \\
\hline & \multicolumn{4}{|c|}{ Summer } \\
\hline NH4-N & $0.24 \pm 0.004$ & $1.07 \pm 0.05$ & $0.92 \pm 0.03$ & $0.27 \pm 0.008$ \\
\hline $\mathrm{NO} 2-\mathrm{N}$ & $0.01 \pm 0.001$ & $0.016 \pm 0.001$ & $0.008 \pm 0.003$ & $0.015 \pm 0.0004$ \\
\hline NO3-N & $0.45 \pm 0.009$ & $0.61 \pm 0.03$ & $0.53 \pm 0.02$ & $0.48 \pm 0.01$ \\
\hline TSIN & $0.7 \pm 0.0$ & $1.7 \pm 0.08$ & $1.46 \pm 0.05$ & $0.76 \pm 0.02$ \\
\hline TDP & $0.06 \pm 0.001$ & $0.28 \pm 0.01$ & $0.16 \pm 0.006$ & $0.06 \pm 0.001$ \\
\hline BAP & $0.0007 \pm 0.0001$ & $0.024 \pm 0.001$ & $0.007 \pm 0.0003$ & $0.002 \pm 0.0006$ \\
\hline \multirow[t]{2}{*}{ BAN } & $0.023 \pm 0.0004$ & $0.3 \pm 0.01$ & $0.04 \pm 0.00$ & $0.02 \pm 0.0006$ \\
\hline & \multicolumn{4}{|c|}{ Autumn } \\
\hline NH4-N & $0.13 \pm 0.003$ & $0.82 \pm 0.04$ & $0.36 \pm 0.01$ & $0.76 \pm 0.02$ \\
\hline $\mathrm{NO} 2-\mathrm{N}$ & $0.015 \pm 0.0003$ & $0.02 \pm 0.001$ & $0.008 \pm 0.0003$ & $0.018 \pm 0.0005$ \\
\hline $\mathrm{NO} 3-\mathrm{N}$ & $0.24 \pm 0.005$ & $0.75 \pm 0.03$ & $0.27 \pm 0.01$ & $0.28 \pm 0.008$ \\
\hline TSIN & $0.4 \pm 0.008$ & $1.59 \pm 0.07$ & $0.54 \pm 0.02$ & $1.06 \pm 0.03$ \\
\hline TDP & $0.036 \pm 0.0007$ & $0.32 \pm 0.02$ & $0.072 \pm 0.003$ & $0.049 \pm 0.001$ \\
\hline BAP & $0.00 \pm 0.0001$ & $0.035 \pm 0.002$ & $0.0024 \pm 0.0001$ & $0.0027 \pm 0.0002$ \\
\hline BAN & $0.04 \pm 0.0008$ & $0.2 \pm 0.01$ & $0.06 \pm 0.002$ & $0.03 \pm 0.0009$ \\
\hline
\end{tabular}

Table5.Quantitative relationship between the chemically analyzed nutrients (TDP and TSIN), and their bioavailable concentrations.

\begin{tabular}{|c|c|c|c|c|c|c|c|c|c|c|c|c|c|c|c|c|}
\hline \multirow{3}{*}{ Ratio } & \multicolumn{16}{|c|}{ Seasons } \\
\hline & \multicolumn{4}{|c|}{ Winter } & \multicolumn{4}{|c|}{ Spring } & \multicolumn{4}{|c|}{ Summer } & \multicolumn{4}{|c|}{ Autumn } \\
\hline & 1 (ref) & 2 & 3 & 4 & 1 & 2 & 3 & 4 & 1 & 2 & 3 & 4 & 1 & 2 & 3 & 4 \\
\hline$\% \mathrm{BAP} / \mathrm{TDP}$ & 4.8 & 3.3 & 2.7 & 9.1 & 6.6 & 3.7 & 3.04 & 10 & 1.4 & 8.6 & 4.4 & 3.3 & 3.8 & 10.9 & 3.4 & 5.5 \\
\hline $\begin{array}{c}\% \text { BAP.EDT } \\
\text { A/TDP } \\
\end{array}$ & 7.8 & 3.8 & 3.2 & 10 & 8.3 & 5.6 & 7.4 & 20 & 3.4 & 9.3 & 10 & 4.0 & 5.0 & 12.5 & 5.5 & 6.3 \\
\hline$\%$ BAN/TSIN & 17.5 & 9.8 & 13.9 & 15.2 & 8.6 & 20.6 & 18.5 & 23.1 & 3.2 & 17.6 & 2.7 & 2.6 & 10 & 12.6 & 11.1 & 2.8 \\
\hline $\begin{array}{c}\% \text { BAN.EDT } \\
\text { A/TSIN }\end{array}$ & 21.6 & 12.7 & 15.6 & 18.3 & 10.6 & 26.4 & 26.3 & 28.7 & 8.5 & 22.3 & 4.7 & 2.9 & 15 & 23.3 & 15.1 & 2.9 \\
\hline
\end{tabular}

1=upstream reference station; 2=Drain (wastewater); 3=Mixing zone; 4=Downstream recovery station 


\subsection{Assessment of heavy metal toxicity}

The effects of heavy metal toxicity on algal growth was reported as $\%$ growth inhibition at 14 day $\left(\% \mathrm{I}_{14}\right)$ based on the difference in mg algal dry weight $1-1$ obtained in EDTA treated and control cultures (Table 6). As shown from Table 6 , the $\% \mathrm{I}_{14}$ displayed remarkable significant $(\mathrm{p} \leq 0.05)$ variations at different sampling stations and seasons with values ranged between $(20 \%-58.6 \%)$, where the lowest value expressing growth inhibition due to metal toxicity was observed at the upstream reference station during autumn and the highest value was recorded at station 4 during summer (Table 6).

Table6. The percent inhibition at day (\%I) based on difference in mg dry wt $/ 1$ obtained in EDTA treated and control cultures

\begin{tabular}{ccccc}
\hline \multirow{2}{*}{ Station } & \multicolumn{4}{c}{ Algal growth inhibition (\% I $\mathbf{I}_{\mathbf{1 4}}$ Season } \\
\cline { 2 - 5 } & winter & spring & summer & autumn \\
\cline { 2 - 5 } & 37 & 23.7 & 34.4 & 50 \\
\hline 1 (Ref.) & 49.6 & 49.34 & 49 & 27.9 \\
\hline 2 & 39.3 & 44 & 42.5 & 47.9 \\
\hline 3 & 47 & 50 & 58.6 & \\
\hline 4 & & & &
\end{tabular}

\subsection{The relationship between observed and expected chlorophyll a}

Figure 7; illustrate both local and seasonal variations in concentration of both observed and expected chlorophyll a. It was clear from Figure 7 that relatively higher concentrations of both observed and expected chlorophyll a were exclusively recorded at station 2 . Substantially very highly significant $(\mathrm{p} \leq$ 0.01) increase in expected chlorophyll a than observed Chl. awas only noticed at station 2 in all seasons, however, is reverse was held true for other stations (Figure 7). Also, as shown in Figure 7 the observed chlorophyll a fluctuated between $6.84 \mathrm{mgl}^{-1}$ (at station 4 during spring) and $47.43 \mathrm{mg} . \mathrm{l}^{-1}$ (at station 2 during spring), While the expected chlorophyll a varied greatly between $3.1 \mathrm{mg} .1^{-1}$ (at station 1 during summer) and $100 \mathrm{mgl}^{-1}$ (at station 2 during autumn).

\subsection{Statistical analysis}

The symbolic presentation of $\%$ coefficient of variance in Table7, which lists the difference in algal maximum standing crop (MSC) between different treatment and control cultures. It is obvious that the growth of the test alga mainly limited by heavy metal toxicity particularly at drain water station (2), mixing zone station (3) and downstream recovery station (4), while there was not significant heavy metal limited to the growth of test alga at upstream reference station (1). Also for most cases the growth of test alga was limited by P followed by $\mathrm{N}$ depending on sampling stations and seasons. However, usually the combined addition of $\mathrm{P}, \mathrm{N}$, and EDTA enhanced highly significant growth of test alga at all station in all seasons.

The result of correlation between chemically analyzed nutrient, their bioavailable and expected chl. a, observed chl. a (Table 8) indicate that total soluble inorganic nitrogen (TSIN) was mainly composed of $\mathrm{NH}_{4}-\mathrm{N}$ as the two parameter showed a highly significant correlation $(\mathrm{r}=0.93)$. The bioavailable nitrogen (BAN) correlated significantly $(\mathrm{p} \leq 0.05)$ and strongly with ammonium-N $(\mathrm{r}=0.65)$ and TSIN $(\mathrm{r}=0.61)$. The bioavailable phosphorus (BAP) maintained significant correlation with $\mathrm{TDP}(\mathrm{r}=0.75)$ and $\mathrm{BAN}(\mathrm{r}=0.81)$. The observed Chl.a showed significant correlation with TDP $(\mathrm{r}=0.82)$, while the expected chl. a correlated significantly with $\mathrm{NH}_{4}-\mathrm{N}$ $(\mathrm{r}=0.73), \operatorname{TSIN}(\mathrm{r}=0.79), \operatorname{TDP}(\mathrm{r}=0.86)$. 

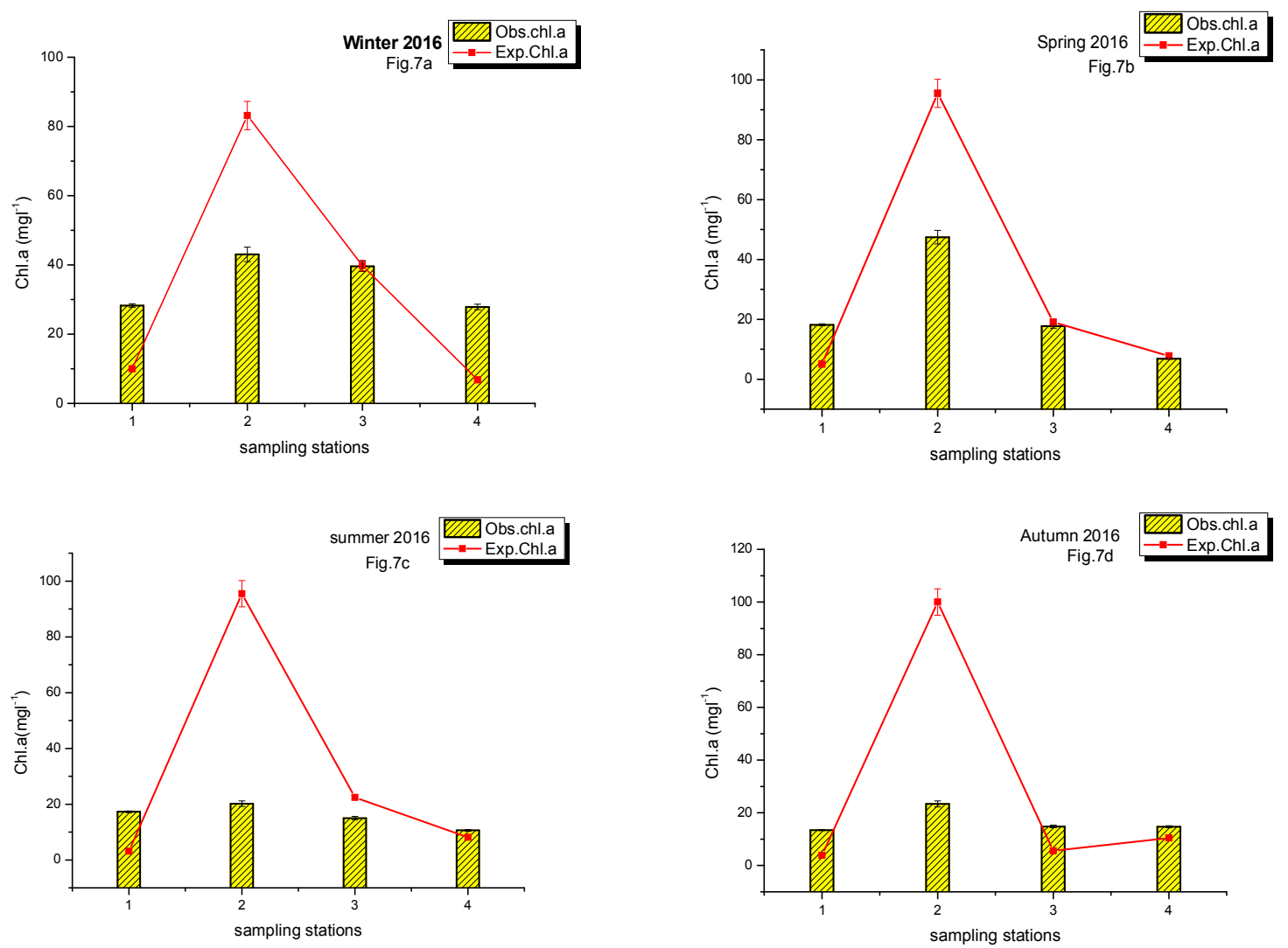

Fig.7. The relationship between the observed (Phytoplankton) and the expected (AGP) chlorophyll.

Table 7. Differences in algal maximum standing crop (MSC) between different treatments and control cultures

\begin{tabular}{|c|c|c|c|c|c|c|c|c|c|c|c|c|c|c|c|c|c|c|c|c|c|c|c|c|c|c|c|c|}
\hline \multirow{2}{*}{ 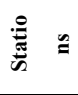 } & \multirow[b]{2}{*}{$\mathbf{A}$} & \multicolumn{4}{|c|}{$\mathbf{C}+\mathbf{P}$} & \multicolumn{4}{|c|}{$\mathrm{C}+\mathrm{N}$} & \multicolumn{3}{|c|}{$\mathbf{C}+\mathbf{P}+\mathbf{N}$} & \multicolumn{5}{|c|}{ C+EDTA } & \multicolumn{3}{|c|}{$\mathbf{C}+\mathbf{P}+$ EDTA } & \multicolumn{5}{|c|}{$\mathrm{C}+\mathrm{N}+$ EDTA } & \multicolumn{3}{|c|}{$\mathbf{C}+\mathbf{P}+\mathbf{N}+$ EDTA } \\
\hline & & $\mathbf{w}$ & SP & SU & $\mathbf{A}$ & $\mathbf{w}$ & SP S & SU & $\mathbf{A}$ & w & SP & SU & $\mathbf{A}$ & w & SP & SU & $\mathbf{A}$ & $\mathbf{w}$ & SP & SU & $\mathbf{A}$ & $\mathbf{w}$ & SP & SU & A & $\mathbf{w}$ & SU & SP \\
\hline $1(\mathrm{ref})$ & $*$ & $*$ & $*$ & $*$ & NS & NS & NS 1 & NS & NS & $*$ & NS & $*$ & NS & NS & NS & NS & $* *$ & $*$ & $*$ & $* *$ & $*$ & $*$ & NS & $*$ & $* *$ & $*$ & $* *$ & $* *$ \\
\hline 2 & NS & NS & NS & NS & $* * *$ & * & * 1 & NS & NS & NS & NS & NS & $* * *$ & $* * *$ & $* * *$ & $* * *$ & $* * *$ & * & * & $* *$ & $* * *$ & $*$ & $* * *$ & NS & $* * *$ & $* *$ & $* * *$ & $* * *$ \\
\hline 3 & * & $* * *$ & $* *$ & $*$ & NS & * & $* *$ & $* * *$ & $* *$ & $* *$ & $* * *$ & $* * *$ & * & $* *$ & $*$ & $*$ & $* *$ & $* * *$ & $* * *$ & NS & * & NS & $* * *$ & $*$ & $* *$ & $* * *$ & $* * *$ & $* * *$ \\
\hline 4 & NS & $* * *$ & * & NS & NS & $* * *$ & $* * *$ & NS & NS & $* * *$ & NS & $*$ & $* *$ & $* *$ & $* *$ & $*$ & NS & $* * *$ & NS & NS & NS & $* * *$ & NS & NS & $* * *$ & $* * *$ & $* * *$ & $* *$ \\
\hline
\end{tabular}

$\mathrm{P}=$ phosphorus; $\mathrm{N}=$ Nitrogen; $\mathrm{C}=$ Control $\mathrm{W}=$ winter; $\mathrm{Sp}=$ spring; $\mathrm{Su}=$ summer; $\mathrm{A}=$ autumn; *Significant (according to the \%C.V guideline presented inTable7); ** Highlysignificant; *** Very high significant; NS = non-significant

Table8.Correlation between $\mathrm{NH}_{3}-\mathrm{N}, \mathrm{NO}_{2}-\mathrm{N}, \mathrm{NO}_{3}-\mathrm{N}$, TSIN, bio-available nitrogen (BAN), total dissolved phosphorus(TDP) and bioavailable phosphorus

\begin{tabular}{|c|c|c|c|c|c|c|c|c|c|}
\hline & NH3-N & NO2-N & NO3-N & TSIN & TDP & BAN & BAP & Obs. Chl a & Exp.Chl a \\
\hline $\mathrm{NH}_{3}-\mathrm{N}$ & 1 & & & & & & & & \\
\hline $\mathrm{NO}_{2}-\mathrm{N}$ & 0.33 & 1 & & & & & & & \\
\hline $\mathrm{NO}_{3}-\mathrm{N}$ & 0.47 & -0.33 & 1 & & & & & & \\
\hline TSIN & $0.93 *$ & 0. & $0.75^{*}$ & 1 & & & & & \\
\hline TDP & $0.74 *$ & $0.55^{*}$ & 0.33 & $0.69 *$ & 1 & & & & \\
\hline BAN & $0.65^{*}$ & 0.43 & 0.29 & $0.61 *$ & $0.72 *$ & 1 & & & \\
\hline BAP & $0.66^{*}$ & 0.21 & $0.62 *$ & $0.75^{*}$ & $0.75^{*}$ & $0.81^{*}$ & 1 & & \\
\hline Obs. Chl a & 0.49 & $0.71 *$ & 0.09 & 0.42 & $0.82 *$ & $0.55^{*}$ & $0.50^{*}$ & 1 & \\
\hline Exp.Chl a & $0.73 *$ & 0.29 & $0.57 *$ & $0.79 *$ & $0.86^{*}$ & $0.85^{*}$ & $0.95^{*}$ & $0.61^{*}$ & 1 \\
\hline
\end{tabular}




\section{Discussion}

The algal bioassays are usually used to identify growth limiting nutrients and to eutrophication potential of aquatic ecosystem (Goldman, 1963; Likens, 1972; Schelske et al., 1978; Paerl and Bowles, 1987; Källqvist and Berge, 1990; Xu et al., 2010). The algal growth potential test seems to be a good tool to formulate a disciplinary guideline for water quality of wastewater drain and the receiving water of the River Nile. In this study, the water fertility, toxicity, and the nutrient limitation and bioavailability of nutrients of wastewater drain and the receiving waters were evaluated. The results (Figures3a-6a) indicated that the drain station 2 maintained the highest maximum standing crop of test algal, followed by mixing station and the recovery station 4 during the study period, while the lowest one was recorded at relatively unpolluted upstream reference station. This finding indicates the hypereutrophic conditions (increase of nitrogen and phosphorus concentrations) of the receiving waters due to the drainage wastewater discharge. Similar results were reported by (Paerl et al., 2011). The wastewater reaching the drain station from agriculture land, domestic and industry may be the main cause for the high water fertility. However, actually more than $80 \%$ of the AGP biomass were less than or equal to $8 \mathrm{mg} 1^{-} \cdot$ a result revealing, so far, a desirable water quality (Vollenweider, 1971; Raschke and Schultz, 1978 )

The AGP was mainly limited by $\mathrm{P}$ in most stations (where the concentration of phosphorus is low)expect the drain station 2,where AGP was mainly limited by heavy metal toxicity followed by nitrogen (Table 7) This finding seems common feature in freshwater ecosystems (Miller et al., 1978; Elser et al., 1990,2007; Kielsina et al.,2001;Schindler et al.,2008). This may attributed due to the presence of considerable high amounts of bioavailable $\mathrm{P}$ at drain waters (Table 4), and the excessive phosphorus should enhance the development of nuisance algal blooms (Schultz, 1985), a condition which has been reported during this study and supported with the highest concentration of observed chl.a (Figure 7). This finding may assumes the validity of other factors controlling $\mathrm{P}$ bioavailability among which total alkalinity (NTAC, 1968), hardness (NAS, 1974), type and amount of suspended solids (Golterman, 1975), N:P ratio (Chiaudani and Vighi, 1974), natural complexities and organic matter content ( Fayed, 1981 ) and heavy metals (Van Donk et al., 1988), may be the most significant.

$\mathrm{N}$ limitation is only observed at stations 2(drain), 3(mixing zone) and 4(recovery zone) (Table 7) due to high pollution condition. The excessive loading of P-rich agricultural fertilizers, domestic wastewater into drain station is actually the main cause of raising $\mathrm{P}$ level and bringing the receiving waters into $\mathrm{N}$ limitation state. This finding, supported by the reports of (Fitzgerald, 1969), (Lee,1973) and (Rhee,1974, 1978),(Forsberg, 1976), (Miller et al., 1978), and (Howarthand Marino, 2006) .
The significant increase in AGP due to combined $\mathrm{P}$ and $\mathrm{N}$ additions (Table 7) was, mainly, attributed to $\mathrm{P}$ addition in case of $\mathrm{P}$ limitation, and to $\mathrm{N}$ when was the growth limiting nutrient. This finding similar to (Hernandez et al., 2001; Bernal-Brook et al., 2003; and Harpole et al., 2011). Always, the combined additions of P, N, and EDTA (Figures 3d - 6d) supported the highest algal biomass production, presumably due to the combined effects of nutrient availability and reduction in heavy metal toxicity (Miller et al., 1978).

The relationships between the chemically analyzed nutrients $(\mathrm{P}$ and $\mathrm{N})$ and their bioavailable concentrations were affected greatly by heavy metal toxicity (Table 5) Similar observations were reported by (Chuiaudani and Vighi, 1974), (Greene et al. 1975, 1978), Miller et al. (1976, 1978), (Permazziet al., 1979), (Fayed 1981), (Van Donk et al., 1988) and (Abdel-Hamid et al., 1992). In many cases, the growth of the test alga was severely inhibited by heavy metal toxicity (Table 6). Generally, the EDTA treated cultures maintained significantly higher algal biomass compared to control (Figures $3 a-6 a$ ) indicating the presence of heavy metal with toxic concentration(Elster\&Komarek,2003). As chelating agent EDTA may reduce metal toxicity through its binding capacity (Gächteret al., 1974 ), keeps trace metals in concentrations available for algal growth (Dufkova, 1984 ) or it facilitates P uptake (Wetzel, 1975). Based on the result of $\% \mathrm{I}_{14}$ indicate that AGP was mainly inhibited by heavy metal toxicity, followed by limitation of $\mathrm{N}$ and $\mathrm{P}$.

Similar to what was observed by Claesson (1978), Klapwijk et al. (1989) and Abdel-Hamid et al. (1992) the observed phytoplankton chlorophyll a, showed no direct interrelationship with the expected chlorophyll a (Figure 7), but showed relation with nutrient especially (TDP) $(r=0.82)$ as the increase of phosphorus lead to high phytoplankton biomass(high observed Chl.a (Table 8) similar finding recorded by Jones et al. (2011). This discrepancy between the observed and the expected chlorophyll a biomass, may be due to the role of other factors governing the growth of natural phytoplankton populations like, for instance, light (Van Donk, 1983), temperature (Kopczynska, 1981), water turbidity (Smith, 1982), nutrient release from the sediments and external loadings (Golterman, 1983), and differences in chlorophyll a content of phytoplankton populations (Nicholls and Dillon, 1978).

\section{Conclusion}

Algal growth potential test (AGPT) proved a good, effective and sensitive mean for assessing the productivity and toxicity of the Omer Bekdrain wastewater and the receiving freshwater of the River Nile. The AGP values were highly related with the heavy metal toxicity and concentrations of $\mathrm{P}$ and $\mathrm{N}$. The highest biomass was recorded at drain station and lowest biomass was recorded at the upstream reference station. The test also assesses heavy metal toxicity contained in water samples. 
List of abbreviation:

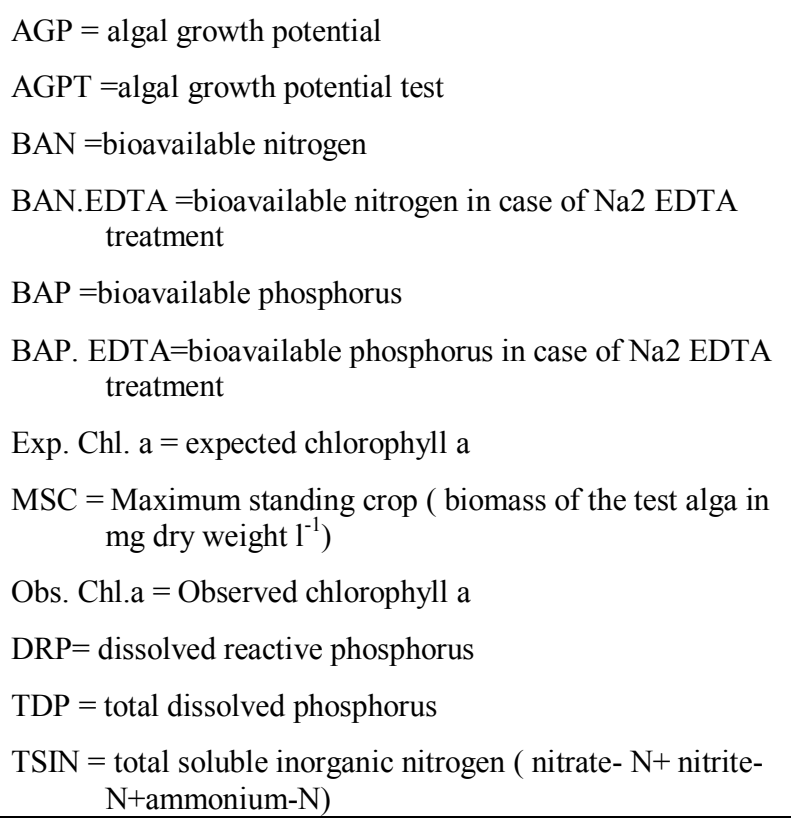

\section{References}

Abdel-Hamid, M.I.; Shaaban-Dessouki, S.A. and Skulberg, O.M. (1992a).Water quality of the River Nile in Egypt. I. Physical and chemical characteristics. Archive fur Hydrobiologie Supplement, 90(3):283-310.

APHA (1998). Standard methods for the examination of water and wastewater. 19th Edition. American Public Health Association, American Water Works Association, Water Pollution Control Federation, Washington, DC.

APHA (2005). Standard Methods for the Examination of Water and Wastewater, 21st ed.; American Public Association: Washington, D.C

ASTM International. (2004). Practice for algal growth potential testing with Pseudokirschneriellasubcapitata; ASTM D3 97804. West Conshohocken, PA: ASTM International.

Bargagli, R. (2001). Trace metals in Antarctic organisms and the development of circumpolar biomonitoring networks. Reviews of Environmental Contamination and Toxicology, 171: 53-110.

Barnes, H. and Folkard, A.R. (1951). The determination of nitrites Analyst, 76(907): 599-603.

Bernal-Brooks, F.W.; Davalos-Lind, L., and Lind, O.T. (2003). Seasonal and spatial variation in algal growth potential and growth-limiting nutrients in a shallow endorheic lake: Lake Patzcuaro (Mexico). Lakes \& Reservoirs: Research \& Management, 8(2): 83-93.
Chiaudani, G. and Vighi, M. (1974). The N: P ratio and tests with Selenastrum to predict eutrophication in lakes. Water Research, 8(2): 1063-1069.

Claesson, A. (1978). Research on recovery of polluted lakes. Algal Growth potential and the availability of limiting nutrients- ACTA Universitatis Upsaliensis, Abstracts of Uppsala Dissertations from the Faculty of Science. 461: $1-27$.

Davalos-Lind, L.; Lind, O. T.; Velarde, G.; Vazques-Rojero, E.; Thompson, J.; Hernandez, G.; Sambrano, J.; Martinez, K.; Mora Lopez, E. (2013). [Aporte de nutrientes de fuentespuntualesydifusas de la subcuenca al lago de Chapala y supotencialparapromovercrecimiento algal]. In: A. Juàrez A (ed.), [Contaminacionagricola y erosion en la cuenca del Lago de Chapala]. [Book in Spanish]. FIDERCO, Mexico.

Dewis, J. and Freitas, F. (1970). Physical and chemical methods of soil and water analysis, Soils Bulletin No. 10. Food and Agriculture organization of the United Nations, Rome.

Donald, D.B.; Bogard, M.J.; Finlay, K.; Bunting, L.; Leavitt, P.R. (2013). Phytoplankton-specific response to enrichment of phosphorus rich surface waters with ammonium, nitrate, and urea. $P$ Lo S One, 8: 1-14.

Dufkova, V. (1984). EDTA in algal culture media. Archive fur Hydrobiologie Supplement, 67 (4): 479-492.

Elser, J.J.; Bracken, M.E.; Cleland, E.E.; Gruner, D.S.; Harpole, W.S.; Hillebrand, H. and Smith, J. E. (2007). Global analysis of nitrogen and phosphorus limitation of primary producers in freshwater, marine and terrestrial ecosystems. Ecology letters, 10(12), 1135-1142.

Elster, J. and Komarek, O. (2003). Ecology of periphyton in a melt water stream ecosystem in the maritime Antarctic. Antarctic Science, 15(2): 189-201.

Fayed, S. (1981). Eutrophication Trends in the River Nile. Egyptian Academy of Scientific Research and Technology, Egypt.

Fayed, S. and Shehata, S. A. (1980). Nutritional status of Nile water in relation to phytoplankton population. Zeitschrift Fur Wasser and Abwasser ForschungJournal For Water And Wastewater Research. 13(2):4551.

Fitzgerald, G.P. (1969). Field and laboratory evaluation of bioassays for nitrogen and phosphorus with algae and aquatic weeds. Limnology and Oceanography, 14(2): 206-212.

Forsberg, C.; Ryding, S. O.; Claesson, A., and Forsberg, Å. (1978). Water chemical analyses and/or algal assay?Sewage effluent and polluted lake water studies. Internationale Vereinigungfür Theoretische und Angewandte Limnologie: Mitteilungen, 21(1): 352-363. 


\section{Journal of Environmental Sciences, 2018; Vol. 47, No. 3-4 : 129-144}

Gächter, R.; LumShue-Chan, K. and Chau, Y.K. (1974). Complexing capacity of the nutrient medium in relation inhibition of algal photosynthesis by copper. Schweizerische Zeitschriftfür Hydrologie, 35(2): 252261.

Gerhold, R. M. (1976). Algal nutritional bioassay of Lake Wylie, North Carolina, p. 175-220 In E. J. Middlebrooks , D. H. Falkenborg, and T. E.Maloney [eds.], Biostimulation and nutrient assessment. Ann Arbor Sci.

Greene, J. C. and Shiroyama, T. (1976). Application of algal assays to define the effects of wastewater effluents upon algal growth in multiple use river systems. p. 77-92 In E. J. Middlebrooks, D. H. Falkenborg, and T. E. Maloney [eds.], Bio stimulation and nutrient assessment. Ann Arbor Sci.

Greene, J. C.; Miller, W. E.; Shiroyama, T., and Maloney, T. E. (1975). Utilization of algal assays to assess the effects of municipal, industrial, and agricultural wastewater effluents upon phytoplankton production in the Snake River system. Water, Air, and Soil Pollution, 4(3-4), 415-434.

Goldman, C.R. (1963). The measurement of primary productivity and limiting factors in freshwater with ${ }^{14}$ C. In: Doty, M. S. (ed.), Proceedings of the conference on primary productivity measurement, marine and freshwater. U.S. Atomic Energy Commission T.I.D. - pp. 103 -113.

Golterman, H. L. (1983). Algal bioassays and algal growth controlling factors in eutrophic shallow lakes. Hydrobiologia, 100(1): 59-64.

Harpole, W. S.; Nagi, J. T.; Borer, E. T.; Bracken, M. E. S.; Elser, J. J.; Gruner, D. S.; Hillebrand, H.; Shurin, J. B. and Smith, J. E. (2011). Nutrient co-limitation of primary producer communities. Ecology letters, 14(9):852-862

Howarth, R.W. and Marino, R. (2006). Nitrogen as the limiting nutrient for eutrophication in coastal marine ecosystem: evolving views over three decades. Limnology and Oceanography, 51:367-376

Jones, J. R.; Obrecht, D.V.and Thorpe, A.P. (2011). Chlorophyll maxima and chlorophyll: total phosphorus ratios in Missouri reservoirs. Lake and reservoir management, 27(4): 321-328.

Källqvist, T. (1975). Algal growth potential of six Norwegian waters receiving primary, secondary and tertiary sewage effluents. Internationale Vereinigungfürtheoretische und angewandte Limnologie: Verhandlungen, 19(3), 2070-2081

Källqvist, T. and and Berge, D. (1990). Biological availability of phosphorus in agricultural runoff compared to other phosphorus sources. Internationale Vereinigungfürtheoretische und angewandte Limnologie: Verhandlungen, 24(1): 214-217.
Kiesling, R.L.; McFarland, A.M.S. and Hauck, L.M. (2001). Nutrient Targets for Lake Waco and North Bosque River: Developing Ecosystem Restoration Criteria. Texas Institute for Applied Environmental Research, Technical Report 0107, Tarleton State University, Stephenville, Texas.

Kuang, Q.; Bi, Y.; Xia, Y. and Hu, Z. (2004). Phytoplankton Community and Algal Growth Potential in Taipinghu Reservoir, Anhui Province, China. Lakes \& Reservoirs: Research \& Management, 9(2): 119-124

Klapwijk, S. P.; Bolier, G. and Van der Does, J. (1989). The application of algal growth potential tests (AGP) to the canals and lakes of western Netherlands. In Environmental Bioassay Techniques and their Application (pp. 189-199). Springer, Dordrecht.

Kopczynska, E.E. (1980). Seasonal variations in phytoplankton in the Grand River mouth area of Lake Michigan. Polish archives of hydrobiology, 27(1): 95124.

Kviderova, J. (2010). Rapid algal toxicity assay using variable chlorophyll fluorescence for Chlorella kesslerii (Chlorophyta). Environmental Toxicology 25(6): 554563.

Lee, G. F. (1973). Role of phosphorus in eutrophication and diffuse source control. In Phosphorus in Fresh Water and the Marine Environment, 7: 111-128

Likens, G. E. (1972). Nutrients and Eutrophication: the limiting nutrient controversy. - Special Symposia Vol. I. Am. Soc. Limnol. Oceanogr. Allen Press, Lawrence, Kansas. 328 pp.

Lopez, E. L.; and Davalos-Lind, L. (1998) .Algal Growth Potential and Nutrient Limitation in a Tropical RiverReservoir System of the Central Plateau, Mexico. Aquatic Ecosystem Health, 1(3-4): 345-351.

Lukavsky, J. (1992). The evaluation of algal growth potential (AGP) and toxicity of water by miniaturized growth bioassay. Water Research, 26(10) :1409-1413

McCormick, P.V. and Stevenson, R.J. (1998). Periphyton as a tool for ecological assessment and management in the Florida Everglades. Journal of Phycology ,34: 726-733

Miller, W. E., \& Greene, J. C. (1978). The Selenastrumcapricornutum Printz algal assay bottle test: Experimental design, application, and data interpretation protocol (Vol. 78, No. 18). OR: Environmental Protection Agency.

Miller, W. E.; Maloney, T. E. and Greene, J. C. (1974). Algal productivity in 49 lake waters as determined by algal assays. Water Research. 8:667-679.

Millican, J. S.; Back, J. A., and McFarland, A. M. (2008). Nutrient Bioassays of Growth Parameters for Algae in the North Bosque River of Central Texas 1.JAWRA Journal of the American Water Resources Association, 44(5): 1219-1230. 


\section{Journal of Environmental Sciences, 2018; Vol. 47, No. 3-4 : 129-144}

National Academy of Science National Academy of Engineering. (1974). Water quality criteria, U.S. Government Printing Office, Washington, D.C.

National Technical Advisory Committee to the Secretary of the Interior. (1968). Water quality criteria. U.S. Government Printing Office, Washington, D.C.

Nicholls, K. H., and Dillon, P. J. (1978). An evaluation phosphorus - chlorophyll - phytoplankton relationships for lakes. Internationale Revue der gesamten Hydrobiologie und Hydrographie, 63(2):141-154.

Paerl, H. W.; Xu, H.; McCarthy, M. J.; Zhu, G.; Qin, B.; Li, Y., and Gardner, W. S. (2011). Controlling harmful cyanobacterial blooms in a hyper-eutrophic lake (Lake Taihu, China): the need for a dual nutrient (N \& $\mathrm{P}$ ) management strategy. Water Research,45(5): 19731983.

Paerl, H.W. and Bowles, N. D. (1987). Dilution bioassays: Their application to assessments of nutrient limitation in hypereutrophic waters. Hydrobiologia 146(3): 265-273.

Payne, A. G. (1976). Application of the algal assay procedure in bio stimulation and toxicity testing, p. 3-28 In E. J. Middle brooks, D. H. Falkenborg, and T. E. Maloney [eds.], Bio stimulation and nutrient assessment. Ann Arbor Sci.

Premazzi, G.; Bertone, R.; Freddi, A., and Ravera, O. (1977). Combined effects of heavy metals and chelating substances on Selenastrum cultures. In Proc. Seminar on Ecological tests relevant to the implementation of proposed regulations concerning environmental chemicals: evaluation and research needs. Berlin (pp. 169-187).

Pers `ic, V. and Horvatic, J. (2011). Spatial distribution of nutrient limitation in the Danube River Floodplain in relation to hydrological connectivity. Wetlands, 31(5):933 -944.

Raschke, R.L., and Schultz, D. A. (1987). The use of algal growth potential test for data assessment. Journal WPCF, 59 (4): 222 - 227.

Rhee, G. Y., and Gotham, I. J. (1980). Optimum N: P ratio and coexistence of planktonic algae. Journal of Phycology 16:486-489.

Rhee, G.Y. (1974). Phosphate uptake under nitrate limitation by Scenedesmussp. and its ecological implications. Journal of Phycology, 10: 470-475.

Rhee, G.Y. (1978). Effects of N: P atomic ratios and nitrate limitation on algal growth, cell composition, and nitrate uptake. Limnology and Oceanography, 23: 10-25.
Schelske, C. L.; Rothman, E. D. and Simmons, M. S. (1978). Comparison of bioassay procedures for growth-limiting nutrients in the Laurentian Great Lakes. Internationale Vereinigungfür Theoretische und Angewandte Limnologie: Mitteilungen, 21(1): 65-80.

Schindler, D. W.; Hecky, R. E.; Findlay, D.L.; Stainton, M. P.; Parker, B.R.; Paterson, M. J.; Beaty, K. G.; Lyng, M. and Kasian, S. E. M. (2008). Eutrophication of lakes cannot be controlled by reducing nitrogen input: Results of a 37-year whole ecosystem experiment. Proceedings of the National Academy of Sciences, 105(32): 1125411258.

Schultz, D. (1985). Lake Greenwood and Boyd Mill Pond algal growth potential test. Environmental Services Division, Ecology Branch, U.S, EPA, Athens, Ga.

Shin, J.K. and Cho, K.J. (2000). The Impact on Water Quality from Blue Green Algae Microcystis Natural Phytoplankton by Algal Assay. Journal of Environmental Science International, 9(6):267-267.

Skulberg, O. M. (1968). Studies on eutrophication of some Norwegian inland waters. Internationale Vereinigungfür Theoretische und Angewandte Limnologie: Mitteilungen, 14: 187 - 200.

Smith, V.H. (1982). The nitrogen and phosphorus dependence of algal biomass in lakes: An empirical and theoretical analysis. Limnology and Oceanography, 27(6): 11011112

U.SEPA (US Environmental Protection Agency) (1971): Algal assay procedure bottle test. - National Eutrophication Research Program, Corvallis, Oregon. USA.

US, EPA (US Environmental Protection Agency). (2002). Methods for evaluating wetland condition: using algae to assess environmental conditions in wetlands. EPA822-R-02-021. Washington, DC: Office of Water, US Environmental Protection Agency.

Wetzel, R. (1975). Seasonal succession of phytoplankton. In: Wetzel, R. (ed.), Limnology. - W. B. Saunders Company.

Xu, H.; Paerl, H. W.; Qin, B.; Zhu, G. and Gao, G. (2010). Nitrogen and Phosphorus Inputs Control Phytoplankton Growth in Eutrophic Lake Taihu, China. Limnology Oceanography, 55(1): 420-432.

Zahran, M. A., Azab-Mohammad, Y. A. and Abdel-Hamid, M. I. (1988). Biological assessment of water pollution of Damietta branch of the River Nile and proposal for its control. - International Workshop on Clean Technology and Pollution Treatment, Cairo (7-9 March, 1988), Egyptian Environmental Affairs Agency (EEAA), Cairo, Egypt. 


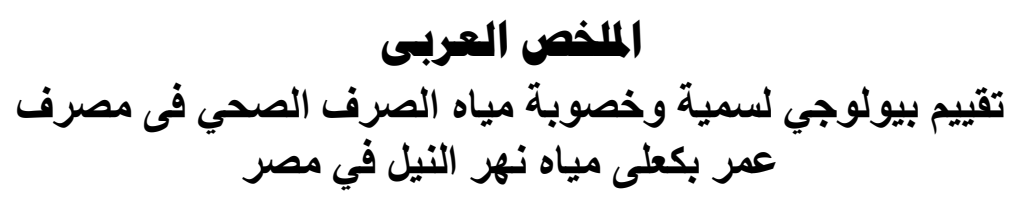

سارة سعد ابراهيمم

غادة سمير ابو الوفا

محمد اسما عيل عبد العميد

قسم النبات ـ كليه العلوم - جامعة المنصورة- مصر

تم تقييم سمية المياه وخصوبة مياه الصرف الصحي لمصرف عمر بيك الذي يصرف مباثرة إلى فرع دمباط من نهر النيل.

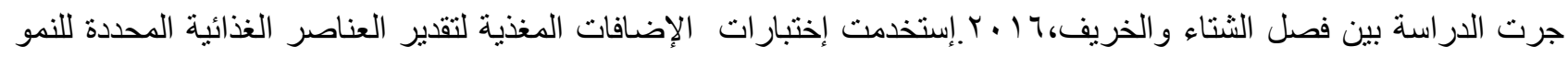
الطحلبي ، وتو افر ها الحيوي ، وسمية المعادن الثقبلة في عينات المياة. وذلك باستخدام طحلب الإختبار القياسي ل سيدوكرشينر لا

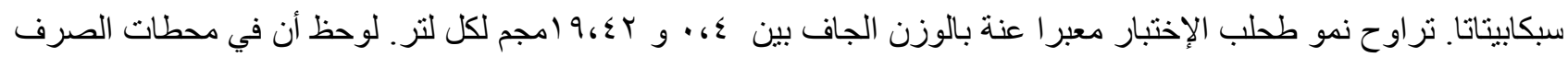
و الإختلاط و الإستعادة كان نمو طحلب الإختبار القياسي قليلا نسبيا بسبب سمية المعادن الثقيلة حيث نراوحت نسبة تثبيط النمو عند

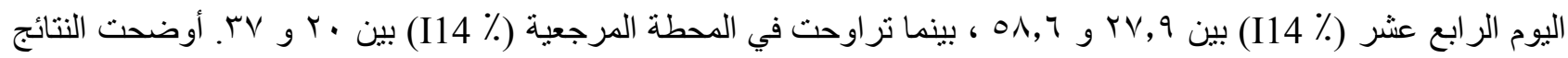
ان نمو طحلب الإختبار تأثر بتركيز عنصري النيتروجين والفسفور وتباينت النتائج من محطة لأخري و من موسم لأخر. كان

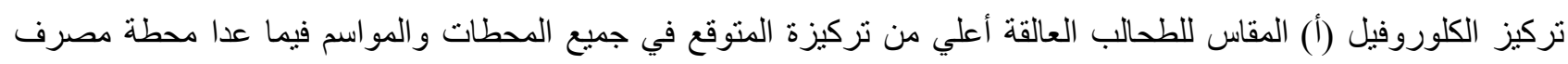

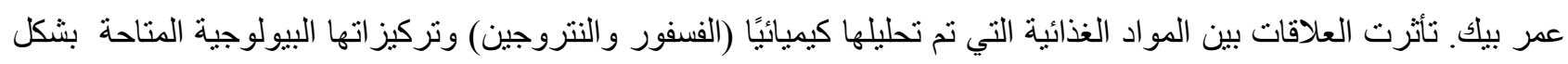

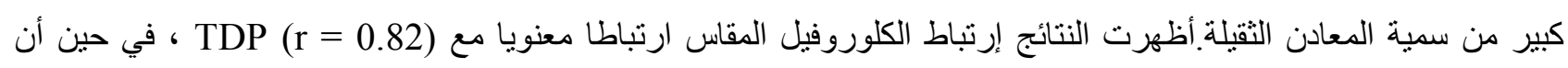
الكلوروفيل المتوقع يرتبط بشكل كبير مع)NH4-N (r = 0.73.أثبت اختبار إمكانات نمو الطحالب أنه وسيلة حساسة ويمكن الاعتماد عليها لتقييم خصوبة المياه وسمية المصارف الملوثة والمياه المستقبلة. 


\section{Journal of Environmental Sciences}

\section{JOESE 5}

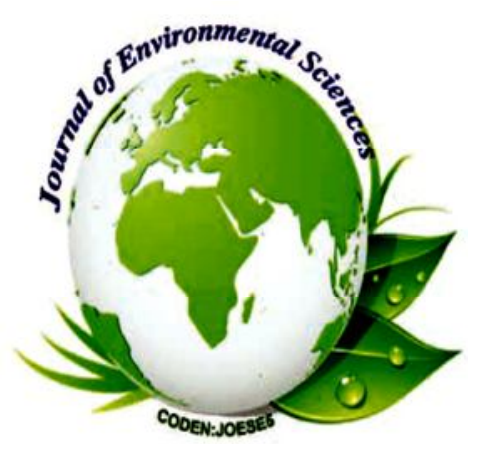

Biological assessment of water toxicity and fertility of wastewater Omer Bek drain discharging into receiving water of the River Nile in Egypt

Ghada S. Abou-El Wafa; Sara S. Ibrahim and Mohammad I. Abdel-Hamid Botany Department, Faculty of Science, Mansoura University, Egypt

\section{Reprint}

Volume 74, Number 3-4 : 129-144

(2018) 